\title{
PENELITIAN
}

\section{Pengaruh Variasi Genetika Cyp2c19 Terhadap Efek Sedasi Midazolam Intravena}

Sukmiasi Sismadi*, Uripno Budiono*

*Bagian Anestesiologi dan Terapi Intensif FK Undip/ RSUP Dr. Kariadi, Semarang

\section{ABSTRACT}

Background: The cytochrome P450 plays an important role in the metabolism of many drugs, chemicals and carcinogens. CYP2C19 is often a major concern because of the high difference in each individual and each population. Based on the capacity of CYP2C19 in the metabolism sustrat, a person can be classified as extensive metabolizers (EM), intermediate metabolizers (IM) and poor metabolizers (PM). Which has the effect of midazolam sedation, anxiolytic, and anterograde amnesia is metabolized through the CYP2C19 enzyme. These drugs are often used as a premedication drug or as a coinduction. In clinical practice that is common with the usual dose of midazolam, not all patients show the expected effect. Therefore, the study of genetic influences on intravenous midazolam biotransformation.

Objectives: Assess the effects of intravenous midazolam on the EM genotype, IM and PM Methods: The study 24 patients undergoing elective surgery in the installation department of the Central Surgical Dr Kariadi Semarang, inclusion and exclusion criteria, with ASA physical status I. Previously people with an explanation of the procedures that will be undertaken and expressed willingness in the sheet informed consent. Desain phase II clinical trials research using cross sectional study to assess the effects of midazolam on the body's metabolic functions. Allele / CYP2C19 polymorphisms were identified by PCRRFLP technique.

Results: The results showed the general characteristics of patients with no laboratory abnormalities, had no complications or side effects of midazolam. Sedation score 5 minutes after administration of midazolam there were no significant differences between men and women $(3.3 \pm 0.59)$, and found no significant association between age with the sedation score $(r=0.250, P=0.183)$. CYP2C19 genotype distribution was found respectively 6 (20\%) of EM, 16 (53.3\%) IM and eight (26.7\%) PM. These three genotypes there were no significant differences by age, sex and sedation score.

Conclusion: There is no significant relationship between the scores of sedation with genotypes EM, IM and PM of CYP2C19.

Keywords: Intravenous Midazolam, metabolism, CYP2C19 


\section{ABSTRAK}

Latar Belakang: Sitokrom P450 berperan penting dalam metabolisme obat, zat kimia dan karsinogen. CYP2C19 sering menjadi perhatian utama karena tingginya perbedaan ditiap individu maupun tiap populasi. Berdasarkan kapasitas CYP2C19 dalam metabolisme sustrat, seseorang dapat dikelompokkan sebagai extensive metabolizers (EM), intermediate metabolizers (IM) dan poor metabolizers (PM). Midazolam yang mempunyai efek sedasi, ansiolitik dan anterograde amnesia dimetabolisme melalui enzim CYP2C19. Obat ini sering digunakan sebagai obat premedikasi ataupun sebagai koinduksi. Pada praktek klinis sering dijumpai dosis midazolam yang lazim, ternyata tidak semua pasien menunjukkan efek yang diharapkan. Diteliti seberapa besar pengaruh genetik terhadap biotransformasi midazolam intravena.

Tujuan: Menilai efek midazolam intravena pada genotipe EM, IM dan PM

Metode: Penelitian pada 24 pasien yang menjalani bedah elektif di Instalasi Bedah Sentral RSUP Dr Kariadi Semarang, yang memenuhi kriteria inklusi dan eksklusi, dengan status fisik ASA I. Sebelumnya penderita mendapatkan penjelasan tentang prosedur yang akan dijalani serta menyatakan kesediaannya dalam informed consent. Desain penelitian uji klinik fase II ini menggunakan cross sectional untuk menilai efek midazolam terhadap fungsi metabolisme tubuh. Alel/polimorfisme CYP2C19 diidentifikasi dengan tehnik PCRRFLP.

Hasil: Dari hasil penelitian menunjukkan karakteristik umum penderita tidak terdapat kelainan laboratorium, tidak mengalami komplikasi atau efek samping terhadap midazolam. Skor sedasi 5 menit setelah pemberian midazolam midazolam tidak terdapat perbedaan yang bermakna antara laki-laki dan perempuan $(3,3 \pm 0,59)$, serta tidak ditemukan hubungan yang bermakna antar usia dengan nilai skor sedasi $(r=0,250$; $P=0,183)$. Distribusi genotip CYP2C19 ditemukan masing-masing 6 (20\%) EM, 16 (53,3\%) IM dan 8 (26,7\%) PM. Ketiga genotip tidak terdapat perbedaan yang bermakna dengan usia, jenis kelamin maupun skor sedasi.

Simpulan: Tidak terdapat hubungan yang bermakna antara nilai skor sedasi dengan genotip EM, IM dan PM dari CYP2C19.

Kata Kunci : Midazolam intravena, metabolisme, CYP2C19 


\section{PENDAHULUAN}

Dosis dan frekuensi yang diperlukan untuk mencapai kadar obat yang efektif dalam darah dan jaringan bervariasi karena adanya perbedaan individu di dalam metabolisme dan eliminasi obat. Perbedaan ini ditentukan oleh faktor genetik dan non genetik seperti umur, jenis kelamin, fungsi hati, irama sirkardian, suhu tubuh dan faktor-faktor nutrisi serta pemaparan bersamaan terhadap induser dan inhibitor metabolisme obat. Perbedaan individu dalam kecepatan metabolisme juga tergantung pada sifat obat sendiri. Jadi dalam individu yang sama, kadar steady state plasma dapat mencerminkan suatu variasi yang sangat besar antara 2 sampai 30 kali dalam metabolisme satu obat. ${ }^{1,2,3}$

Sitokrom P450 berperan penting dalam banyak metabolisme obat, zat kimia dan karsinogen. CYP2C19 sering menjadi perhatian utama karena tingginya perbedaan di tiap individu maupunpopulasi. Berdasarkan kapasitas CYP2C19 dalam memetabolisme substrat, seseorang dapat dikelompokkan sebagai extensive metabolizers (EM), intermediate metabolizer (IM) dan poor metabolizer (PM). Konsentrasi cycloguanil yang merupakan metabolit dari proguanil, berbeda secara bermakna diantara ketiga grup berdasarkan jumlah dari alel mutan (Kruskal Wallis, $\mathrm{P}<0,05$ ). Hasil ini menggambarkan hubungan antara genotip CYP2C19 dan metabolisme proguanil, serta peningkatan suatu efek dosis gen. ${ }^{4}$
Biotransformasi atau metabolisme obat adalah proses perubahan struktur kimia obat yang terjadi dalam tubuh dan dikatalisa oleh enzim. Pada proses ini molekul obat diubah menjadi lebih polar (lebih mudah larut dalam air) dan kurang larut dalam lemak sehingga lebih mudah diekskresi melalui ginjal. Selain itu, pada umumnya obat menjadi inaktif, sehingga biotransformasi sangat berperan dalam mengakhiri kerja obat. Akan tetapi, ada beberapa obat yang metabolitnya masih mempunyai aktifitas farmakologik yang sama atau berbeda dengan obat asalnya dan yang dapat menyebabkan efek toksik obat. Beberapa obat lain yang merupakan calon obat (prodrug) justru diaktifkan oleh enzim biotransformasi ini. Metabolit yang aktif akan mengalami biotransformasi lebih lanjut atau ekskresi yang mengakhiri kerjanya. 1,2,3,4,5

Pada tahun 1977, Kupfer dan kawankawan melaporkan metabolisme stereooselektif dari mephentoin dan metabolit $N$-dimethyl pada hewan. ${ }^{6}$ Setelah itu ditemukan bahwa 4 hydroxilatixylate dari s-mephenytoin bersifat polimorfik, sekitar $3 \%$ dari Kaukasian yang PM.

Dua defek pada gen CYP2C19 bertanggung jawab pada metabolisme yang buruk dari s-mephenytoin yang diperlihatkan oleh Morais dan kawankawan. Mutan M1 disebabkan oleh $\mathrm{G}^{681} \rightarrow \mathrm{A}$ mutasi pada exon 5, yang membentuk pada tempat penyambungan yang menyimpang. Mutasi ini merusak 
tempat pembelahan sel pada DNA melalui tes PCR yang dapat dikembangkan. Midazolam (8-chloro-6(2-fluorophenyl)-1-methyl-4Himidazol$(1,5-a)(1,4)$ benzodiazepine) merupakan benzodiazepine agonist yang mempunyai sifat ansiolitik, sedatif, antikonvulsif dan anterograd amnesia.,

Obat ini banyak digunakan perioperatif. Sediaan komersial dibuffer pada $\mathrm{pH} 3,5$ untuk menjaga kestabilan dalam air, potensinya $1,5-2$ kali diazepam. Midazolam pada $\mathrm{pH}$ netral dan basa larut dalam air dan dapat dicampur dalam larutan infus seperti $\mathrm{NaCl} 0,9 \%$ atau glukosa 5\% yang tetap stabil secara fisik maupun kimiawi untuk 24 jam pada suhu kamar. ${ }^{8}$

Asam gama-aminobutirat (GABA) adalah penghambat neurotransmiter yang utama pada SSP. Penelitian elektrofisiologi menunjukkan bahwa benzodiazepin menguatkan neurotransmisi GABAergik pada semua tingkat neuroaksis, yang mencakup medula spinalis, hipotalamus, hipokampus, substansia nigra, korteks serebeli dan korteks serebri.

Benzodiazepin tampaknya meningkatkan efisiensi inhibisi sinaptik GABAergik (melalui membran hiperpolarisasi) yang menyebabkan penurunan kecepatan pencetusan neuron yang krisis dalam banyak regio otak. Benzodiazepin tidak menggantikan GABA, tetapi tampaknya meningkatkan efek GABA tanpa aktivasi reseptor GABA secara langsung atau saluran klorida yang berhubungan.
Peningkatan konduksi klorida menyebabkan interaksi benzodiazepin dengan GABA yang menyebabkan peningkatan frekuensi kejadian terbukanya saluran. Efek ini mungkin sebagian disebabkan oleh meningkatnya afinitas untuk GABA. ${ }^{7,9}$

Tujuan penelitian ini untuk mengetahui pengaruh midazolam intravena pada efek sedasi pasien dengan genotipe EM, IM dan PM.

\section{METODE}

Penelitian ini merupakan cross sectional yang akan menilai efek midazolam terhadap fungsi metabolisme tubuh. Sampel penelitian merupakan penderita yang menjalani operasi elektif dengan anestesi umum. Di Instalasi Bedah Sentral RSUP Dr. Kariadi Semarang. Diseleksi berdasarkan kriteria inklusi dan eksklusi dan drop out.

Kriteria Inklusi : umur 16 sampai <40 tahun (dewasa muda), BMI (Body Mass Index) $20-25 \mathrm{Kg} / \mathrm{m}^{2}$, status fisik ASA I. Kriteria Eksklusi : mengkonsumsi obatobatan yang dapat mempengaruhi metabolisme obat penelitian dalam 1 minggu preoperasi, tidak ada riwayat penyakit hati, gangguan metabolisme tubuh dan sering terpapar pestisida. Kriteria drop out : Penderita mengalami efek samping yang memerlukan terapi sebelum dinilai.

Sampel yang diperlukan dalam penelitian ini sebanyak 24 orang. Genotip CYP2C19 diperiksa dengan menggunakan teknik PCR-RFLP 
(Polymerase chain reaction-restriction length polymorphism). DNA diisolasi dari darah tepi dengan menggunakan teknik standar yang digunakan dilaboratorium bioteknologi pusat kegiatan penelitian UNHAS.

Setelah mendapatkan informed consent, subyek dipuasakan 6 jam sebelum operasi dan dibawa keruang operasi tanpa jalur intravena dan premedikasi. Setelah sampai di ruang operasi dilakukan pemasangan jalur intravena sekaligus mengambil sampel darah sebanyak $10 \mathrm{cc}$ dan infus $\mathrm{NaCl} 0,9 \%$, kemudian dipasang monitor standar rutin dan diberikan midazolam $0,07 \mathrm{mg} / \mathrm{kgbb}$ intravena bolus. Waktu pemberian midazolam disebut menit ke-0 dan pada menit ke-5 dinilai skor sedasi dengan 4 skala pengukuran seperti yang digunakan oleh field et al (Field Score) ${ }^{7-10}$.

Skor :

1. Aktif (Alert/active)

2. Bangun/tenang (Awake/calm)

3. Mengantuk, respon terhadap suara (drowsy but respon verbal)

4. Tertidur (asleep)

Pasien kemudian diinduksi sementara itu sampel darah dimasukkan kedalam kotak khusus sebagai transport dan dibawa ke laboratorium biomolekuler untuk analisa genetik tipe dari sitokrom $\mathrm{P} 450$ pasien termasuk poorl normall extensive metabolism).

Data yang terkumpul selanjutnya diberi kode, ditabulasi dan dimasukkan sebagai data komputer. Analisa data meliputi analisis deskriptif dan uji hipotesis menggunakan program SPSS 13.0.

\section{HASIL}

Jumlah subjek penelitian 30 orang yang terdiri dari 15 perempuan dan 15 laki-laki dengan berbagai jenis tindakan operasi. Tidak ditemukan kelainan laboratorium pada semua subjek penelitian. Usia ratarata subjek penelitian $30,6 \pm 8,18$ tahun, tidak terdapat perbedaan yang bermakna pada usia rata-rata antara perempuan $(29,66 \pm$ 7,04 tahun) dan laki-laki $(31,53$ $\pm 9,34$ tahun), ( $>0,05)$. Semua subjek yang mengikuti penelitian ini tidak mengalami komplikasi atau efek samping terhadap midazolam.

Nilai rata-rata skor sedasi 5 menit setelah pemberian midazolam 3,3 $\pm 0,59$. Tidak terdapat perbedaan yang bermakna nilai skor sedasi pada perempuan $(3,4 \pm 0,5)$ dan laki-laki $(3,2 \pm 0,67)$, $(\mathrm{p}<0,05)$. Tidak ditemukan hubungan yang bermakna antara usia dengan nilai skor sedasi $(r=0,250 ; \mathrm{P}-0,183)$.

Dari 30 subjek yang diteliti, ditemukan distribusi genotip CYP2C19 masingmasing $6(20 \%)$ genotip extensive metabolizer (EM), $16 \quad(53,3 \%)$ intermediate metabolizer (IM) dan 8 $(26,7 \%)$ poor metabolizer (PM). Tidak terdapat perbedaan yang bermakna antara ketiga genotip tersebut dengan usia, jenis kelamin maupun skor sedasi. 


\section{PEMBAHASAN}

Telah diteliti nilai skor sedasi pada 30 subjek yang mendapat $0,07 \mathrm{mg} / \mathrm{kgBB}$ midazolam intravena dikaitkan dengan genotip dari CYP2CI9. Nilai skor sedasi didasarkan atas respon kognitif subjek 5 menit setelah diberikan midazolam intravena. Nilai skor sedasi yang diperoleh pada penelitian ini berkisar 2 sampai dengan 4. Variasi dalam nilai skor sedasi setelah pemberian midazolam dapat dijelaskan melalui 2 hal : variasi kadar plasma midazolam (variasi farmakokinetik) dan variasi dalam sensitifitas terhadap midazolam (variasi farmakokinetik) diantara subjek yang diteliti.

Variasi skor sedasi pada penelitian ini kemungkinan lebih disebabkan oleh faktor farmakodinamik dibandingkan faktor farmakokinetik. Beberapa penelitian sebelumnya telah membuktikan bahwa orang dengan usia lanjut lebih sensitif terhadap efek sedasi benzodiazepin. Orang usia lanjut membutuhkan dosis lebih rendah dibandingkan orang yang lebih muda untuk mencapai efek sedasi yang sama. Pada penelitian ini dapat dilihat pada dua subjek dengan usia muda (16 tahun) nilai sedasinya hanya dua setelah pemberian midazolam.

Walaupun faktor farmakodinamik dianggap lebih berperan dalam menentukan skor sedasi pada penelitian ini, tidak berarti bahwa faktor farmakokinetik sama sekali tidak berperan. Tidak adanya hubungan yang bermakna antara skor sedasi dengan genotip PM dan EM dari CYP2C19 belum dapat menyingkirkan peran faktor farmakokinetik.

Bila faktor farmakokinetik lebih berperan, maka penelitian ini menghasilkan dua hal penting dalam pemberian midazolam. Pertama, midazolam merupakan pilihan yang aman bagi subjek yang mempunyai genotip PM untuk CYP2C19, karena enzim ini bukan merupakan jalur utama metabolisme midazolam, tetapi menjadi jalur utama metabolisme diazepam. Kedua, pemberian midazolam bersama dengan obat-obat yang menghambat CYP3A4, seperti diazepam, anti jamur dan opioid akan mempunyai konsekuensi klinik yang perlu diwaspadai. Obat-obat di atas akan menghambat aktifitas enzim tersebut, sehingga kemampuannya untuk memetabolisme midazolam akan menurun. Konsekuensinya adalah memanjangnya amnesia dan terjadinya gangguan psikomotor. ${ }^{11}$

\section{SIMPULAN}

Dari hasil penelitian ini, disimpulkan bahwa tidak terdapat hubungan yang bermakna antara nilai skor sedasi dengan genotip EM, IM dan PM dari CYP2C19. Ada tiga hal yang kemungkinan dapat menjelaskan temuan tersebut. Pertama, kadar midazolam dalam plasma mengikuti model dua kompartemen dan obat masih dalam fase distribusi, belum berada dalam fase eliminasi, lima menit setelah pemberian intravena. Kedua, CYP2C19 bukanlah enzim utama yang 
memetabolisme midazolam. Ketiga, faktor farmakodinamik lebih berperan dibandingkan faktor farmakokinetik, walaupun faktor ini tidak dapat diabaikan. Perlu dilakukan penelitian mengenai efek sedasi midazolam dikaitkan dengan kadar midazolam dalam darah. Selain itu untuk menilai apakah faktor farmakodinamik dan faktor farmakokinetik yang lebih berperan dalam efek sedasi midazolam.

\section{DAFTAR PUSTAKA}

1. Holford NHG, Benet. LZ. Farmakokinetik \& Farmakodinamik: Pemilihan Dosis yang rasional \& Waktu Kerja Obat. Dalam : Katzung BG (ed). Farmakologi Dasar \& Klinik. Terjemahan Anwar Agus. Jakarta : EGC, 1998 : 36-51)

2. Correia MA. Biotransformasi Obat. Dalam : Katzung BG (ed). Farmakologi Dasar \&Klinik. Terjemahan Anwar Agus, Jakarta : EGC, 1998 : 53-64)

3. Setiawati A, Bustami ZS, Setiabudy R. Pengantar Farmakologi. Dalam : Gan S. Farmakologi dan Terapi. Edisi 3. Jakarta: Bagian Farmakologi FKUI, 1987 : 49-63.

4. Yusuf I, Djojosubroto MW, Ikawati Lum K, Kaneko A, Marzuki M Ethnic and geographical distributions of CYP2C19 alleles in the populations of southeast asia. Adv Exp Med Biol. 2003.

5. Lamba JK, Dhiman RK, Kohli KK. CYP2C19 genetic mutations in North Indian. Clin Pharmacol Ther 2000; 68:328-35.

6. Kimura M, leiri I, Mamiya K, Urae A, Higuchi S, Genetic Polymorphism of cytochrome P450s, CYP2C19 and CYP2C9 in Japanese population. Ther Drug Monit 1998;20:243-7

7. Amrein R,Hetzel W, Allen SR. Co-induction of Anaesthesia: The Rationale.Euro $\mathrm{J}$ of Anaesth 1995;12:5-11.

8. Clarke RSJ. Intravenous Anaesthetic Agent: Induction and Maintenance. In: Healy TEJ, Cohen PJ,eds. A Practice of Anaesthesia, $6^{\text {th }}$ ed London: Edward Arnold 1995: 91-101.

9. Collin VJ. Intravenous Anesthesia: Nonbarbiturates-Nonnarcotics. In: Collin VJ, Ed. Principles of Anesthesiology, $3^{\text {rd }}$ ed. Philadelphia: Lea and Febiger 1993: 756-63.

10. Setiawat A, Setiabudy R. Adrenergik. Dalam: Gan S. Farmakologi dan Terapi. Edisi 3. Jakarta: Bagian Farmakologi FKUI 1987: 49-63.

11. Hamaoka N, Oda I and Asada A. Cytochrome P4502B6 and 2C6 do not metabolize midazolam: kinetik analisis and inhibition study with monoclonal antibodies. Br J Anaesth 2001; 86:540-4. 